\title{
Soya lecithin and season affect the productive performance, nutrient digestibility and blood constituents of growing rabbits
}

\author{
Y.A. Attia ${ }^{1,2}$, A.E. Abd El-Hamid², M.C. de Oliveira, ${ }^{3,5}$, K.I. Kamel $^{4}$, E.M. Qota ${ }^{4}$, \\ M.A. Al-Harthi ${ }^{1}$ and T.A. Sadaka ${ }^{4}$ \\ ${ }^{1}$ King Abdulaziz University, Faculty of Meteorology, Environment and Arid Land Agriculture, Arid Land Agriculture Department, \\ Jeddah 21589, Saudi Arabia \\ ${ }^{2}$ Damanhour University, Faculty of Agriculture, Animal and Poultry Production Department, Damanhour 22516, Egypt \\ ${ }^{3}$ University of Rio Verde, Faculty of Veterinary Medicine, Rio Verde, 75.909-429, Brazil \\ ${ }^{4}$ Animal Production Research Institute, Agriculture Research Center, Alexandria 21917, Egypt
}

KEY WORDS: feed supplements, nutrition physiology, rabbit finishing, soyabean by-products

Received: 23 April 2017

Revised: 6 August 2017

Accepted: 15 January 2018

${ }^{5}$ Corresponding author:

e-mail: mcorv@yahoo.com.br
ABSTRACT. This study was performed to determine the effect of different levels of soya lecithin (SL) added to the diets for growing V-line rabbits in the winter and summer seasons. One hundred sixty 35 -day-old rabbits were used in two experiments, one was conducted in the winter and the other in the summer (each for 49 days). Animals were randomly assigned to 4 experimental groups and fed diet supplemented with $0,0.5,1.0$ and $1.5 \%$ of SL. The addition of SL to the diet improved weight gain, feed intake and feed conversion ratio in both seasons. Body weight gain and carcass traits were improved by the inclusion of SL in the summer $(P<0.05)$. Dietary SL increased $(P<0.05)$ ether extract apparent faecal digestibility, levels of triglycerides, total lipids, phospholipids, high-density lipoprotein cholesterol (HDL), and the enzymatic activity of acid phosphatase, whereas decreased $(P<0.05)$ the levels of total cholesterol and low-density lipoprotein cholesterol (LDL), and the activities of aspartate amino transferase and alanine amino transferase in the blood. In the winter, lower nutrient digestibility coefficients and lower relative weights of the heart and spleen were found. In the summer season the elevated $(P<0.05)$ blood levels of glucose, $\mathrm{HDL}$ and LDL were observed in comparison to the winter season. Supplementation of feed with $1 \%$ or $1.5 \%$ SL improved rabbit growth performance, fat digestibility and HDL blood level in both seasons. So, the soya lecithin can be a useful feed additive also in the heat stress conditions.

\section{Introduction}

In the summer in Egypt and in many other countries, the rabbit production declines pronouncedly causing a drop in productive and economic benefits. Animal performance may be influenced by the heat stress and consequently the depression of feed intake (Marai et al., 2005).
It is known that the higher temperature, the smaller number of solid meals eaten and the more water drunk (Gidenne et al., 2010). In the study of Zeferino et al. (2011) on straightbred and crossbred Botucatu rabbits maintained at $30{ }^{\circ} \mathrm{C}$ from 5 to 10 weeks of age, the feed intake decreased by $21 \%$ and growth rate by $18 \%$ in comparison to the animals kept at $18{ }^{\circ} \mathrm{C}$. Moreover, high temperature 
in the summer season is the most important factor that influences the post-weaning mortality. According to Habeeb et al. (1997) and Shehata et al. (1998), mortality rate may be even $18 \%$ during the summer.

The mean temperature in Egypt is about 34 and $22{ }^{\circ} \mathrm{C}$ in the summer and winter, respectively. In the summer, the temperature much higher than the comfort temperature for rabbits $\left(18-21^{\circ} \mathrm{C}\right)$ causes a heat stress condition. In order to improve the productive and physiological performance of rabbits during the summer season in Egypt, several feed supplements have been studied (Attia et al., 2011). Among them is soya lecithin (SL) - a mixture of natural phospholipids, phosphatidylcholine (PC), phosphatidylethanolamine and phosphatidylinositol. On average PC, phosphatidylethanolamine and inositol phosphatides in SL constitute 19-21\%, 8-20\% and 20-21\%, respectively (Scholfield, 1981), and phosphatidylserine $0.2-6.3 \%$ (Liu and Ma, 2011).

SL improves the productive and reproductive performance of laying hens and rabbit bucks and is a good source of unsaturated fatty acids, antioxidants and energy (Attia et al., 2009; Attia and Kamel, 2012). PC from biliary sources increased lymphatic triglyceride absorption in Wistar rats which might be connected with the packaging and secretion of chylomicrons (Nishimukai et al., 2003).

In Egypt rabbit breeding season normally begins in October and ends in April with the oncoming summer season. Heat stress occurs in these animals when they are not able to regulate their heat homeostasis passively, and the reduction in white and red blood cells counts and the increase in blood cholesterol content may be observed (Ondruska et al., 2011).

Feed additive supplements, such as SL, can improve nutrient utilization, blood parameters and productive performance during the summer season due to its antioxidant properties. Thus, the aim of the study was to determine the effect of different levels of SL in the diet during the winter and summer season on growth performance, ability to digest nutrients and blood parameters of $\mathrm{V}$-line growing rabbits raised from 35 to 84 days of age.

\section{Material and methods}

The present study was carried out at El-Sabahiea Poultry Research Station, Alexandria Governorate, Animal Production Research Institute, Agriculture Research Centre (Egipt). The experiment design was approved by the Animal Production Research Institute Scientific and Ethics Committee (Protocol No. 04-05-03-37).

\section{Experimental design and diets}

In total, 160 35-day-old V-line growing rabbits with the average initial body weight of $748 \pm 148 \mathrm{~g}$ were used in two experiments, with 40 males and 40 females in each. The experiments were run from January to February (winter) and from July to August (summer), each for 49 days. The rabbits were randomly assigned to 4 experimental groups with 20 animals per group, in each season. Animals were housed separately in galvanized wire cages (dimensions $50 \times 45 \times 40 \mathrm{~cm}$ ) and fed 4 different diets: control (without SL addition) and experimental with $0.5,1.0$ and 1.5\% SL inclusion levels to pelleted feed. Animals had ad libitum access to pelleted feed and water throughout the experiment (from 35 to 84 days of age).

The determination of the SL fatty acid profile in the diets (Table 1) was performed with the use of Shimadzu Gas Chromatograph GC-4CM (Shimadzu Corp., Kyoto, Japan) with a field-effect mobility $(\mathrm{pFE})$ connected to a glass column $(3 \mathrm{~m} \times 3.1 \mathrm{~mm}$ ID; cat no. 221-14368-31, Shimadzu Corp., Kyoto, Japan) packed with $5 \%$ diethylene glycol succinate (DEGS) and equipped with a flame ionization detector (FID) according to Radwan (1978). Fat was extracted prior to GC analysis according to Folch et al. (1957).

\section{Measurements}

Rabbits were weighed at day 35 (initial body weight) and 84 of age (final body weight) and the body weight gain (BWG) was calculated. The amount of consumed feed was also monitored to determine the feed intake (FI) and the feed conversion ratio (FCR). Survival rate was also determined.

At day 65 of age, five male rabbits from each treatment were moved to metabolic cages to estimate the apparent digestibility. The animals were housed individually for 5 days of adaptation and 5 days of collection period. During the collection period, daily faeces were collected and the amount of consumed feed was measured. The collected faeces were collected, and faecal samples were dried in the oven at $60{ }^{\circ} \mathrm{C}$ for $72 \mathrm{~h}$, finely ground, and kept under room temperature until further chemical analysis.

Samples of commercial pelleted feed and faeces were analysed for dry matter (DM), crude protein $(\mathrm{CP})$, ether extract (EE), crude fibre $(\mathrm{CF})$ and ash content according to the AOAC (2007) methods. Organic matter (OM) and nitrogen-free extract (NFE) were also determined. The nutrients digestibility coefficient was calculated using balance method. 
Table 1. Ingredients and chemical composition of diets fed to V-line rabbits

\begin{tabular}{|c|c|c|c|c|}
\hline \multirow[t]{2}{*}{ Indices } & \multicolumn{4}{|c|}{$\begin{array}{l}\text { Dietary soyabean lecithin, } \\
\mathrm{g} \cdot \mathrm{kg}^{-1}\end{array}$} \\
\hline & 0 & 5 & 10 & 15 \\
\hline \multicolumn{5}{|l|}{ Ingredients } \\
\hline clover hay & 400 & 400 & 400 & 400 \\
\hline yellow maize & 100 & 87 & 70 & 55 \\
\hline barley & 130 & 140 & 140 & 140 \\
\hline wheat bran & 150 & 163 & 180 & 200 \\
\hline soyabean meal & 175 & 170 & 170 & 165 \\
\hline soyabean lecithin & 0 & 5 & 10 & 15 \\
\hline molasses & 30 & 20 & 15 & 10 \\
\hline dicalcium phosphate & 8 & 8 & 8 & 8 \\
\hline sodium chloride & 3 & 3 & 3 & 3 \\
\hline vitamin and mineral premix ${ }^{1}$ & 3 & 3 & 3 & 3 \\
\hline DL-methionine & 1 & 1 & 1 & 1 \\
\hline \multicolumn{5}{|c|}{ Analysed and calculated composition, $\mathrm{g} \cdot \mathrm{kg}^{-1}$} \\
\hline dry matter ${ }^{2}$ & 897 & 898 & 897 & 898 \\
\hline crude protein ${ }^{2}$ & 172 & 172 & 174 & 175 \\
\hline crude fibre $^{3}$ & 143 & 144 & 145 & 147 \\
\hline ether extract ${ }^{2}$ & 34 & 39 & 44 & 49 \\
\hline nitrogen free extract ${ }^{3}$ & 560 & 553 & 544 & 545 \\
\hline digestible energy ${ }^{3}, \mathrm{MJ} \cdot \mathrm{kg}^{-1}$ & 11.69 & 11.62 & 11.53 & 11.42 \\
\hline $\mathrm{Ca}^{3}$ & 13.0 & 13.0 & 13.0 & 13.0 \\
\hline available $\mathrm{P}^{3}$ & 3.6 & 3.6 & 3.6 & 3.6 \\
\hline total methionine ${ }^{3}$ & 3.6 & 3.6 & 3.6 & 3.6 \\
\hline total sulphur amino acid ${ }^{3}$ & 6.8 & 6.8 & 6.8 & 6.8 \\
\hline total lysine ${ }^{3}$ & 9.3 & 9.3 & 9.3 & 9.3 \\
\hline \multicolumn{5}{|c|}{ Analysed fatty acid composition, $\mathrm{g} \cdot \mathrm{kg}^{-1}$ of total fatty acids } \\
\hline capric acid $(\mathrm{C} 10: 0)^{4}$ & 62.7 & 36.1 & 70.7 & 46.2 \\
\hline lauric acid $(\mathrm{C} 12: 0)^{4}$ & 61.0 & 51.0 & 3.60 & 4.70 \\
\hline myristic acid $(\mathrm{C} 14: 0)^{4}$ & 47.8 & 10.4 & 47.1 & 56.6 \\
\hline palmitic acid $(\mathrm{C} 16: 0)^{4}$ & 224.8 & 191.8 & 130.6 & 95.9 \\
\hline palmitoleic acid $(C 16: 1 n-7)^{4}$ & 0.00 & 25.9 & 30.2 & 34.2 \\
\hline stearic acid $(\mathrm{C} 18: 0)^{4}$ & 81.7 & 42.5 & 35.2 & 28.9 \\
\hline oleic acid $(C 18: 1 n-9)^{4}$ & 300.1 & 291.2 & 263.5 & 246.5 \\
\hline linoleic acid $(C 18: 2 n-6)^{4}$ & 180.1 & 283.2 & 388.7 & 458.2 \\
\hline arachidic acid $(\mathrm{C} 20: 0)^{4}$ & 41.8 & 67.9 & 30.4 & 28.9 \\
\hline saturated fatty acid (SFA) & 519.9 & 399.7 & 317.6 & 260.8 \\
\hline unsaturated fatty acid (UFA) & 480.1 & 600.3 & 682.4 & 738.9 \\
\hline polyunsaturated fatty acid (PUFA) & 180.1 & 283.2 & 388.7 & 458.2 \\
\hline monounsaturated fatty acid (MUFA) & 300.1 & 317.1 & 293.7 & 280.7 \\
\hline SFA:UFA & 1.08 & 0.67 & 4.70 & 3.50 \\
\hline MUFA:UFA & 0.62 & 0.53 & 0.43 & 0.38 \\
\hline MUFA:PUFA & 1.67 & 1.12 & 0.76 & 0.61 \\
\hline PUFA:UFA & 0.38 & 0.47 & 0.57 & 0.62 \\
\hline
\end{tabular}

${ }^{1}$ per kg: IU: vit $A 6000$, vit $D_{3} 450$; $m$ g: vit $E 40$, vit $K_{3} 1$, vit $B_{1} 1$, vit $B_{2} 3$, vit $B_{3} 180$, vit $B_{6} 39$, vit $B_{12} 2.5$, pantothenic acid 10 ; biotin 10 , folic acid 2.5, choline chloride 1200, Mg 15, Zn 35, Fe 38, Cu 5, Co 0.1, I 0.2 and Se $0.05 ;{ }^{2}$ analysed values according to AOAC International (2007) methods (dry matter - 925.09; crude protein - 999.04D; ether extract 55-1976; ash - 923.03); ${ }^{3}$ calculated values according to Sauvant et al. (2004), Gaafar et al. (2010) and Khalel et al. (2014); ${ }^{4}$ analysed values according to Radwan et al. (1978)

Before slaughter on the last day of experiment (84 day of rabbit age) blood samples $(5 \mathrm{ml})$ were collected from 6 rabbits (randomly chosen 3 females and
3 males) per treatment per season. Blood was taken from the marginal ear vein under vacuum into the heparinized tubes. Plasma samples were obtained by centrifugation of the blood at $1750 \mathrm{~g}$ for $20 \mathrm{~min}$, and stored at $-20{ }^{\circ} \mathrm{C}$ until analysis of the biochemical parameters.

The plasma levels of glucose, total protein, albumin, urea, creatinine, total lipids, phospholipids, triglycerides, total cholesterol, low-density lipoprotein cholesterol (LDL) and high-density lipoprotein cholesterol (HDL), and the activities of the acid phosphatase (ACP), alkaline phosphatase (ALP), lactate dehydrogenase (LDH), aspartate aminotransferase (AST) and alanine aminotransferase (ALT) were determined using commercial kits produced by Diamond Diagnostics Company (Giza, Egypt). Globulin was calculated by determining the difference between total protein and albumin.

At the end of experiment rabbits were fasted with free water supply for $18 \mathrm{~h}$ before slaughter by Islamic method (sharp knife is used to cut the windpipe (throat), food-tract (oesophagus) and the two jugular veins) (Attia et al., 2016). The dressing percentages of carcass with head and proportions of the organs were determined according to Blasco and Ouhayoun (1993).

\section{Statistical analyses}

The data were analysed by a two-way ANOVA using the software SISVAR $^{\circledR}$ (Ferreira, 2011) that considered the main effects of SL and season, and their interactions. Tukey's test was used to detect significant differences among the groups means.

\section{Results}

\section{Climate conditions}

The range from minimal to maximal and average environmental temperature and relative humidity were $16.6-29.6{ }^{\circ} \mathrm{C}, 22.3{ }^{\circ} \mathrm{C}, 39.6-78.8 \%$ and $57.4 \%$ in the winter and $25.3-38.4{ }^{\circ} \mathrm{C}, 32.0^{\circ} \mathrm{C}, 31.3-78.9 \%$ and $54 \%$ in the summer. Since the thermoneutral zone for rabbits is from 18 to $21{ }^{\circ} \mathrm{C}$ (Habeeb et al., 1998) the average temperatures in the summer and winter indicated that pronounced heat stress conditions were more often observed in the summer (average temperature $11^{\circ} \mathrm{C}$ higher than neutral one for rabbits).

\section{Nutrient utilization}

In animals fed diets with 1.0 and $1.5 \%$ addition of SL the EE apparent digestibility increased $(P<0.05)$ progressively without significant effect on the other nutrients. The coefficients of apparent 
Table 2. Effect of soya lecithin (SL) supplementation and season on nutrient apparent digestibility coefficients and ash retention in V-line rabbits between 65 and 70 day of age

\begin{tabular}{|c|c|c|c|c|c|c|c|}
\hline Treatments & DM & OM & $\mathrm{CP}$ & $\mathrm{EE}$ & $\mathrm{CF}$ & Ash & NFE \\
\hline \multicolumn{8}{|c|}{ Effect of SL supplementation, \% } \\
\hline 0.0 & 79 & 60 & 63 & $56^{c}$ & 58 & 56 & 60 \\
\hline 0.5 & 79 & 60 & 64 & $61^{\mathrm{bc}}$ & 59 & 56 & 60 \\
\hline 1.0 & 79 & 60 & 64 & $66^{\mathrm{ab}}$ & 58 & 56 & 61 \\
\hline 1.5 & 79 & 61 & 64 & $68^{a}$ & 59 & 56 & 61 \\
\hline \multicolumn{8}{|c|}{ Effect of the season } \\
\hline winter & 79 & $57^{\mathrm{b}}$ & $60^{\mathrm{b}}$ & $50^{\mathrm{b}}$ & $54^{b}$ & $52^{b}$ & $58^{b}$ \\
\hline summer & 79 & $63^{a}$ & $67^{a}$ & $66^{a}$ & $63^{a}$ & $60^{\mathrm{a}}$ & $62^{\mathrm{a}}$ \\
\hline SEM & 1 & 1 & 1 & 1 & 1 & 2 & 1 \\
\hline \multicolumn{8}{|l|}{$P$-values } \\
\hline SL & 0.907 & 0.983 & 0.851 & 0.001 & 0.852 & 0.985 & 0.926 \\
\hline season & 0.585 & 0.001 & 0.001 & 0.001 & 0.001 & 0.001 & 0.001 \\
\hline SL $\times$ season & 0.768 & 0.917 & 0.924 & 0.922 & 0.974 & 0.991 & 0.929 \\
\hline
\end{tabular}

$\mathrm{n}=5$ per treatmentper season; $\mathrm{DM}$-dry matter; $\mathrm{OM}$-organic matter; $\mathrm{CP}$-crude protein; $\mathrm{EE}$-ether extract; $\mathrm{CF}$-crude fibre; $\mathrm{NFE}$-nitrogen-free extract; ${ }^{a b c}$ - means with different superscripts within each column are significantly different at $P<0.05$

digestibility of CP, EE, CF, NFE, OM, and ash were lower during the winter than in the summer season. There was no effect $(P>0.05)$ of the SL supplementation $\times$ season interactions on nutrient digestibility (Table 2).

\section{Growth performance}

Survival rate was not affected $(P>0.05)$ by the treatments. The $\mathrm{SL} \times$ season interaction affected $(P<0.05)$ FBW, BWG, FI and FCR. The FI of rabbits fed control diet was the same in both seasons, but the FCR was lower and FBW and BWG were higher in the winter. When SL was added to the diets, FBW and BWG were improved and FI was reduced and FCR was improved in both seasons, however, the values of FBW, BWG and FI were higher and FCR was better during the winter (Table 3 ).

\section{Carcass traits and inner organs}

In winter in rabbits fed diets supplemented with $1.5 \%$ of SL the relative heart weight was reduced, whereas in control rabbits relative spleen weight

Table 3. Effect of soya lecithin (SL) supplementation and season on productive performance ${ }^{1}$ and carcass traits ${ }^{2}(\%)$ of V-line rabbits at 84 day of age (the end of experiment)

\begin{tabular}{|c|c|c|c|c|c|c|c|c|c|c|}
\hline \multirow{2}{*}{ Treatments } & \multirow{2}{*}{$\begin{array}{l}\text { FBW, } \\
\mathrm{g}\end{array}$} & BWG & $\mathrm{FI}$ & \multirow{2}{*}{$\begin{array}{l}\text { FCR, } g \text { feed } \cdot g^{-1} \\
\text { BWG }\end{array}$} & \multirow{2}{*}{$\frac{S R}{\%}$} & \multirow[t]{2}{*}{ Carcass } & \multirow[t]{2}{*}{ Liver } & \multirow[t]{2}{*}{ Heart } & \multirow[t]{2}{*}{ Kidney } & \multirow[t]{2}{*}{ Spleen } \\
\hline & & $g \cdot d^{-1}$ & & & & & & & & \\
\hline \multicolumn{11}{|c|}{ SL supplementation, \% } \\
\hline 0.0 & $1588^{c}$ & $18.69^{b}$ & $98.84^{a}$ & $5.28^{\mathrm{a}}$ & 93.75 & $48.87^{\mathrm{b}}$ & $3.44^{a}$ & $0.32^{\mathrm{a}}$ & 0.71 & $0.06^{c}$ \\
\hline 0.5 & $1659^{b}$ & $19.61^{\mathrm{b}}$ & $89.45^{b}$ & $4.56^{\mathrm{b}}$ & 96.25 & $51.81^{a}$ & $3.10^{b}$ & $0.33^{\mathrm{a}}$ & 0.65 & $0.07^{\mathrm{ab}}$ \\
\hline 1.0 & $1820^{a}$ & $21.73^{\mathrm{a}}$ & $89.67^{b}$ & $4.12^{\mathrm{c}}$ & 97.50 & $53.64^{a}$ & $3.43^{\mathrm{a}}$ & $0.31^{\mathrm{a}}$ & 0.66 & $0.08^{a}$ \\
\hline 1.5 & $1792^{\mathrm{a}}$ & $21.33^{a}$ & $90.22^{b}$ & $4.23^{c}$ & 100.00 & $51.87^{a}$ & $3.41^{\mathrm{a}}$ & $0.27^{\mathrm{b}}$ & 0.67 & $0.07^{\mathrm{ab}}$ \\
\hline \multicolumn{11}{|l|}{ Season } \\
\hline winter & 1720 & $24.90^{\mathrm{a}}$ & $95.20^{\mathrm{a}}$ & $3.83^{b}$ & 98.12 & 50.60 & $3.86^{\mathrm{a}}$ & $0.28^{b}$ & 0.68 & $0.05^{b}$ \\
\hline summer & 1704 & $18.06^{b}$ & $90.47^{b}$ & $5.00^{\mathrm{a}}$ & 95.62 & 52.02 & $3.09^{b}$ & $0.32^{\mathrm{a}}$ & 0.67 & $0.08^{a}$ \\
\hline \multicolumn{11}{|c|}{ Effect of the SL supplementation $(\%) \times$ season interaction } \\
\hline $0.0 \times$ winter & $1639^{c}$ & $22.76^{c}$ & $99.16^{\mathrm{a}}$ & $4.36^{c}$ & 95.00 & $45.30^{c}$ & $3.63^{\mathrm{bc}}$ & 0.33 & $0.68^{\mathrm{ab}}$ & 0.04 \\
\hline $0.5 \times$ winter & $1638^{c}$ & $25.35^{b}$ & $94.14^{b}$ & $3.71^{\mathrm{d}}$ & 97.50 & $53.43^{b}$ & $3.25^{c}$ & 0.29 & $0.67^{\mathrm{ab}}$ & 0.05 \\
\hline $1.0 \times$ winter & $1814^{\mathrm{ab}}$ & $26.10^{\mathrm{a}}$ & $92.86^{b}$ & $3.55^{\mathrm{d}}$ & 100.00 & $51.01^{b}$ & $4.50^{\mathrm{a}}$ & 0.26 & $0.75^{\mathrm{a}}$ & 0.06 \\
\hline $1.5 \times$ winter & $1789^{b}$ & $25.43^{\mathrm{ab}}$ & $94.67^{b}$ & $3.72^{\mathrm{d}}$ & 100.00 & $52.67^{b}$ & $4.05^{\mathrm{a}}$ & 0.25 & $0.65^{b}$ & 0.05 \\
\hline $0.0 \times$ summer & $1486^{d}$ & $16.65^{d}$ & $98.65^{a}$ & $5.92^{\mathrm{a}}$ & 92.50 & $50.65^{b}$ & $3.34^{c}$ & 0.31 & $0.73^{a}$ & 0.07 \\
\hline $0.5 \times$ summer & $1698^{b}$ & $16.76^{d}$ & $87.10^{c}$ & $5.19^{b}$ & 95.00 & $50.99^{b}$ & $3.03^{\text {cd }}$ & 0.34 & $0.65^{b}$ & 0.08 \\
\hline $1.0 \times$ summer & $1909^{a}$ & $19.57^{\circ}$ & $88.08^{c}$ & $4.50^{\circ}$ & 95.00 & $54.96^{\mathrm{a}}$ & $2.90^{\mathrm{d}}$ & 0.34 & $0.62^{b}$ & 0.08 \\
\hline $1.5 \times$ summer & $1805^{a}$ & $19.29^{c}$ & $88.00^{c}$ & $4.56^{c}$ & 100.00 & $51.46^{b}$ & $3.09^{c d}$ & 0.28 & $0.68^{\mathrm{ab}}$ & 0.07 \\
\hline SEM & 15.35 & 0.01 & 0.86 & 0.09 & 2.33 & 0.77 & 0.14 & 0.02 & 0.02 & 0.004 \\
\hline \multicolumn{11}{|l|}{$P$-values } \\
\hline$S L$ & 0.001 & 0.001 & 0.001 & 0.001 & 0.317 & 0.001 & 0.037 & 0.028 & 0.072 & 0.001 \\
\hline season & 0.314 & 0.001 & 0.001 & 0.001 & 0.295 & 0.081 & 0.001 & 0.013 & 0.317 & 0.001 \\
\hline SL $\times$ season & 0.001 & 0.008 & 0.045 & 0.015 & 0.901 & 0.002 & 0.001 & 0.099 & 0.001 & 0.127 \\
\hline
\end{tabular}

${ }^{1} \mathrm{n}=20$ per treatment per season; ${ }^{2} \mathrm{n}=6$ per treatment per season; FBW - final body weight; BWG - body weight gain; FI - feed intake; FCR - feed conversion ratio; SR - survival rate; ${ }^{a-d}$ - means with different superscripts within each column are significantly different at $P<0.05$ 
was lower. In the summer higher relative weights of the heart and spleen were observed (Table 3 ).

SL supplementation $\times$ season interaction influenced $(P<0.05)$ the carcass yield, and liver and kidney relative weights. In the winter, SL supplementation increased the carcass yield regardless of dose and liver relative weight but only when 1 and $1.5 \%$ of SL was added. The relative weight of kidney was higher in group supplemented with $1.5 \%$ $\mathrm{SL}$ in comparison to group with $1 \% \mathrm{SL}$ but both these groups did not differ from control group. In the summer, SL at $1 \%$ increased the carcass yield, but reduced the liver and kidney relative weights in comparison to the control diet (Table 3).

\section{Blood parameters}

$\mathrm{SL}$ inclusion at 1 and/or $1.5 \%$ resulted in higher $(P<0.05)$ levels of triglycerides, total lipids, phospholipids, and HDL and decreased $(P<0.05)$ levels of total cholesterol and LDL, and the LDL:HDL ratio in the blood. Higher $(P<0.05)$ levels of glucose, HDL:LDL, and LDL:HDL ratios were found in the summer than in the winter (Table 4). The SL supplementation also reduced $(P<0.05)$ the blood urea level by $7.8 \%$ when added at $1.5 \%$. The enzymatic activities of AST and ALT were lower $(P<0.05)$ in all supplemented groups and the activities of ACP and LDH were increased $(P<0.05)$ when SL was added in the amount of 1 and $1.5 \%$ (Table 5).

Table 4. Effect of soya lecithin (SL) supplementation and season on blood biochemical profile of V-Line rabbits at 84 day of age

\begin{tabular}{|c|c|c|c|c|c|c|c|c|c|c|c|}
\hline \multirow{2}{*}{ Treatments } & Glucose & TG & TP & Alb & $\mathrm{Glb}$ & $\mathrm{TL}$ & PL & $\mathrm{TCH}$ & $\mathrm{HDL}$ & LDL & \multirow{2}{*}{ LDL : HDL } \\
\hline & \multicolumn{2}{|l|}{$\mathrm{mg} \cdot \mathrm{dl}^{-1}$} & \multicolumn{3}{|l|}{$\mathrm{g} \cdot \mathrm{dl}^{-1}$} & \multicolumn{5}{|l|}{$\mathrm{mg} \cdot \mathrm{dl}^{-1}$} & \\
\hline \multicolumn{12}{|c|}{ SL supplementation, \% } \\
\hline 0.0 & 111 & $39.59^{c}$ & 6.68 & 3.25 & 3.42 & $457^{c}$ & $185^{\mathrm{b}}$ & $128^{a}$ & $43.91^{c}$ & $62.45^{a}$ & $0.229^{a}$ \\
\hline 0.5 & 111 & $46.09^{b}$ & 6.55 & 3.22 & 3.33 & $496^{b}$ & $200^{\mathrm{ab}}$ & $121^{b}$ & $50.33^{b}$ & $57.37^{\mathrm{b}}$ & $0.200^{b}$ \\
\hline 1.0 & 109 & $49.20^{a}$ & 6.65 & 3.26 & 3.38 & $512^{b}$ & $214^{\mathrm{ab}}$ & $116^{c}$ & $57.83^{a}$ & $53.29^{c}$ & $0.167^{b}$ \\
\hline 1.5 & 112 & $50.87^{a}$ & 6.70 & 3.27 & 3.43 & $537^{a}$ & $228^{a}$ & $117^{c}$ & $57.12^{\mathrm{a}}$ & $53.16^{c}$ & $0.154^{b}$ \\
\hline \multicolumn{12}{|l|}{ Season } \\
\hline winter & $109^{b}$ & 46.17 & 6.61 & 3.27 & 3.33 & 500 & 208 & 120 & $50.70^{b}$ & $54.66^{b}$ & $0.178^{b}$ \\
\hline summer & $113^{a}$ & 46.70 & 6.69 & 3.23 & 3.45 & 501 & 206 & 121 & $53.89^{a}$ & $58.47^{a}$ & $0.197^{a}$ \\
\hline SEM & 3 & 1.25 & 0.08 & 0.05 & 0.11 & 11 & 12 & 2 & 1.91 & 1.56 & 0.01 \\
\hline \multicolumn{12}{|l|}{$P$-values } \\
\hline $\mathrm{SL}$ & 0.749 & 0.001 & 0.331 & 0.829 & 0.802 & 0.001 & 0.008 & 0.001 & 0.001 & 0.001 & 0.001 \\
\hline season & 0.027 & 0.547 & 0.199 & 0.263 & 0.136 & 0.931 & 0.821 & 0.211 & 0.002 & 0.001 & 0.027 \\
\hline SL $\times$ season & 0.069 & 0.963 & 0.613 & 0.671 & 0.855 & 0.768 & 0.899 & 0.795 & 0.618 & 0.926 & 0.930 \\
\hline
\end{tabular}

n = 6 per treatment per season; TG - triglycerides; TP - total proteins; Alb - albumin; Glb - globulin; TL - total lipids; PL - phospholipids; TCH - cholesterol; HDL - high-density lipoprotein cholesterol; LDL - low-density lipoprotein cholesterol; abc - means with different superscripts within each column are significantly different at $P<0.05$

Table 5. Effect of soya lecithin (SL) supplementation and season on renal and hepatic functions in V-Line rabbits at 84 day of age

\begin{tabular}{|c|c|c|c|c|c|c|c|c|c|}
\hline \multirow{2}{*}{ Treatments } & \multirow{2}{*}{\multicolumn{2}{|c|}{$\begin{array}{l}\text { Urea } \\
\mathrm{mg} \cdot \mathrm{dl}^{-1}\end{array}$}} & \multirow{2}{*}{ Urea : Creatinine } & \multirow{2}{*}{$\frac{\text { ALP }}{U \cdot I^{-1}}$} & \multirow[t]{2}{*}{ ACP } & \multirow[t]{2}{*}{ AST } & \multirow[t]{2}{*}{ ALT } & \multirow{2}{*}{ AST : ALT } & \multirow{2}{*}{$\frac{\mathrm{LDH}}{\mathrm{U} \cdot \mathrm{I}^{-1}}$} \\
\hline & & & & & & & & & \\
\hline \multicolumn{10}{|c|}{ SL supplementation, \% } \\
\hline 0.0 & $45.91^{\mathrm{a}}$ & 1.32 & 34.75 & 176 & $48.20^{c}$ & $53.75^{a}$ & $29.75^{a}$ & 1.81 & $279^{b}$ \\
\hline 0.5 & $44.17^{\mathrm{ab}}$ & 1.29 & 34.21 & 170 & $51.25^{b}$ & $48.00^{\mathrm{b}}$ & $26.41^{b}$ & 1.84 & $290^{\mathrm{b}}$ \\
\hline 1.0 & $44.37^{\mathrm{ab}}$ & 1.30 & 33.98 & 169 & $53.83^{\mathrm{ab}}$ & $46.53^{b}$ & $23.91^{c}$ & 1.95 & $320^{a}$ \\
\hline 1.5 & $42.33^{b}$ & 1.29 & 32.67 & 175 & $55.08^{\mathrm{a}}$ & $44.75^{b}$ & $22.58^{c}$ & 1.99 & $349^{a}$ \\
\hline \multicolumn{10}{|l|}{ Season } \\
\hline winter & 44.56 & 1.31 & 33.91 & 172 & 52.10 & 48.20 & 25.33 & 1.92 & 313 \\
\hline summer & 43.83 & 1.29 & 33.90 & 173 & 52.08 & 48.33 & 26.00 & 1.88 & 306 \\
\hline SEM & 1.07 & 0.02 & 1.04 & 4 & 1.32 & 1.68 & 1.11 & 0.11 & 14 \\
\hline \multicolumn{10}{|l|}{$P$-values } \\
\hline$S L$ & 0.018 & 0.497 & 0.250 & 0.175 & 0.001 & 0.001 & 0.001 & 0.274 & 0.001 \\
\hline season & 0.342 & 0.236 & 0.993 & 0.741 & 0.982 & 0.917 & 0.402 & 0.568 & 0.517 \\
\hline SL $\times$ season & 0.585 & 0.802 & 0.438 & 0.368 & 0.888 & 0.916 & 0.920 & 0.973 & 0.977 \\
\hline
\end{tabular}

$\mathrm{n}=6$ per treatment per season; ALP - alkaline phosphatase; ACP - acid phosphatase; AST - aspartate aminotransferase; ALT - alanine aminotransferase; LDH - lactate dehydrogenase; abc - means with different superscripts within each column are significantly different at $P<0.05$ 


\section{Discussion}

SL as an emulsifier may promote the incorporation of fatty acids in micelles, which increases fat absorption in the intestine and could explain the better EE digestibility. In animals fed diet with $1.5 \%$ SL PUFA content was increased up to $154 \%$ in comparison to the control group, and so confirms the fact that digestibility of dietary fats is influenced by the fatty acid profile with a positive relationship between degree of unsaturation of fats and their digestibility (Maertens et al., 1986). The higher digestibility coefficients of most nutrients during the summer season resulted from the high ambient temperature that causes lower feed intake and decreased digesta passage rate (Arca et al., 1999), and so extend the time of nutrient digestion and absorption. In addition, heat stress may lead to an increase in the activity of the amylase (Routman et al., 2003) and lipase (Hao et al., 2012), which could increase NFE and EE digestibility. However, the values of nutrient digestibility observed herein are lower than those reported by Ondruška et al. (2010), Strychalski et al. (2014) and Zwoliński et al. (2017) and could be attributed to rabbit age and breed, season of the year, environmental conditions and analytical procedure. Strychalski et al. (2014) also mentioned that nutrient digestibility may differ by more than $10 \%$ and is related to the animal age, health, diet and genetic line. Our results, however, are close to the values obtained by Al-Dobaib (2010) in V-line rabbits.

Animal performance. The reduction in FI due to the SL supplementation is caused by the lower gastric emptying rate - phosphatidylcholine enhances the lymphatic output of chylomicron, which are important stimuli of cholecystokinin (CCK) secretion by dietary lipids, and CCK suppresses gastric emptying (Nishimukai et al., 2003). Reduced BWG during summer season in comparison to the winter is connected with declination of energy intake during heat conditions. FBW and BWG were higher in rabbits fed diets with 1 or $1.5 \%$ than in control group and in rabbits raised during the winter season $(+37.9 \%)$. Since BWG values were higher in rabbits raised during the winter, FCR was also better in comparison to the summer, mainly due to SL supplementation. Survival rate was not influenced by the treatments and varied from 92.50 to $100 \%$.

Carcass traits. PUFA present in SL may exert a protective effect on the heart by improving the energy efficiency in this muscle (Abdukeyum et al., 2008). Diets enriched with PUFA increase antioxidant enzyme expression and decrease mito- chondrial reactive oxygen species (Anderson et al., 2014) which may protect the spleen and increase its proportion. Higher energy availability for protein deposition and so better carcass yield may be due to SL supplementation improving lipid metabolism in the body. In the diets with 1 or $1.5 \%$ addition of SL, the higher PUFA content than SFA content leads to higher metabolizable energy (Celebi and Utlu, 2004). In addition, under heat stress conditions, metabolizable energy is inadequate to sustain the processes of protein synthesis and diverts energy and protein away from growth (Attia et al., 2003). Also, the liver relative weight can be improved by SL inclusion to the diet since lipogenesis occurs primarily in the liver, and this effect may be correlated with enhanced lipid metabolism in this organ. In addition, PUFA present in the diets containing SL can protect hepatocytes by inhibiting liver cell peroxidation as shown by Qiu et al. (2012). In the summer, lower liver relative weight was noted since during the hot season the FI was lower and so the capillary blood flow decreased in the internal organs.

Blood parameters. Higher levels of triglycerides, total lipids and phospholipids in the blood were found in animals fed diets with SL addition which as an emulsifier increases fat absorption in the gut (Attia et al., 2009; Attia and Kamel, 2012). In addition, triglyceride levels were also dependent on the level of hepatic lipogenesis. Huang et al. (2008) noted that SL affected the expression of hepatic genes involved in lipid metabolism, particularly those genes regulating lipogenesis, which also explains the higher triglycerides in the blood. Also, dietary lecithin could modify the cholesterol homeostasis in the liver; lecithin reduces excess LDL and promotes the synthesis of great amount of HDL in the liver (Lin et al., 2004). Le Blanc et al. (2003) reported that the effect of SL was associated with cholesterol that was rapidly directed for elimination in the bile or converted to bile acids. The high content of PUFA in the experimental diets might also reduce plasma cholesterol, since PUFA can increase the activity of the LDL receptor, decrease LDL apoB pool size and increase LDL fractional catabolic rate (Ramprasath et al., 2012).

During the summer blood glucose levels were higher because of the lower energy metabolism during heat stress associated with lower plasma levels of insulin and thyroxin (Habeeb et al., 1996). The hot season also increased the levels of HDL and LDL cholesterol and the LDL:HDL ratio. This might be due to an increased activity of 3-hydroxy3-methylglutaryl-coenzyme A reductase, which is 
the limiting enzyme in cholesterol synthesis (Endo, 1992). In the study of Ondruska et al. (2011) conducted on rabbits raised at 18 or $36^{\circ} \mathrm{C}$ the higher blood cholesterol levels were stated in heat-stressed rabbits. Higher levels of HDL and LDL cholesterol could be attributed to higher cholesterol synthesis, as HDL and LDL cholesterol are involved in the transportation of cholesterol in the body, as reported by Kalmath et al. (2013).

Enzyme activity. PUFA can regulate the expression of enzymes involved in carbohydrate and lipid metabolism. According to Cavaliere et al. (2016), n-3 PUFA decreases mitochondrial efficiently, particularly in the skeletal muscles, which may result in higher lactate production and consequently higher conversion of lactate to pyruvate by $\mathrm{LDH}$.

ALT and AST are important liver markers, and the results of the presented study suggest a protective effect of SL on liver cells. As SL increases the activity of the antioxidant enzymes, it may protect cells against the oxidative stress and from the presence of elevated levels of AST and ALT in the serum. Dewi (2016) also reported a reduction in AST and ALT in rats fed diets with lecithin and $\mathrm{CCl}_{4}$, indicating a protective effect of SL against liver injury. This effect was attributed to the antioxidant properties of SL.

\section{Conclusions}

Supplementing V-line rabbit diets with soya lecithin at the amount of 1 and $1.5 \%$ improves growth performance, fat digestibility and increases the level of high-density lipoprotein cholesterol in the blood during both summer and winter seasons. So, the soya lecithin can be a useful feed additive also in the heat stress conditions.

\section{Acknowledgements}

The article was funded by the Deanship of Scientific Research (DSR), King Abdulaziz University, Jeddah, Saudi Arabia. Therefore, the authors would like to thank DSR for technical and financial support.

\section{References}

Abdukeyum G.G., Owen A.J., McLennan P.L., 2008. Dietary (n-3) longchain polyunsaturated fatty acids inhibit ischemia and reperfusion arrhythmias and infarction in rat heart not enhanced by ischemic preconditioning. J. Nutr. 138, 1902-1909

Al-Dobaib S.N., 2010. Effect of diets on growth, digestibility, carcass and meat quality characteristics of four rabbit breeds. Saudi J. Biol. Sci. 17, 83-93, https://doi.org/10.1016/j. sjbs.2009.12.012
Anderson E.J., Thayne K.A., Harris M., Shaikh S.R., Darden T.M., Lark D.S., Williams J.M., Chitwood W.R., Kypson A.P., Rodriguez E., 2014. Do fish oil omega-3 fatty acids enhance antioxidant capacity and mitochondrial fatty acid oxidation in human atrial myocardium via PPARy activation? Antioxid. Redox Signal. 21, 1156-1163, https://doi.org/10.1089/ars.2014.5888

AOAC International, 2007. Official Methods of Analysis of AOAC International. $18^{\text {th }}$ Edition. $2^{\text {nd }}$ Revision. Gaithersburg, MD (USA)

Arca F.D., Alba L.M.P., Hernández M.P., 1999. Digestibility and energy retention by young rabbits fed different levels of intake. Ann. Zootech. 48, 289-295, https://doi.org/10.1051/animres:19990405

Attia A.I., Hassan I.I., El-Zaiat A.A., Abd El-Maksoud A.A., 2003. Effect of dietary oil and ascorbic acid on the performance of broiler chicks under Egyptian summer conditions. Egypt. J. Nutr. Feed. 6, 3-4

Attia Y.A., Al-Hanoun A., Bovera F., 2011. Effect of different levels of bee pollen on performance and blood profile of New Zealand White bucks and growth performance of their offspring during summer and winter months. J. Anim. Physiol. Anim. Nutr. 95, 17-26, https://doi.org/10.1111/j.1439-0396.2009.00967.x

Attia Y.A., Bovera F., Abd El-Hamid A.E., Tag El-Din A.E., AlHarthi M.A., El-Shafy A.S., 2016. Effect of zinc bacitracin and phytase on growth performance, nutrient digestibility, carcass and meat traits of broilers. J. Anim. Physiol. Anim. Nutr. 100, 485-491, https://doi.org/10.1111/jpn.12397

Attia Y.A., Hussein A.S., Tag El-Din A.E., Qota E.M., Abed El-Ghany A.I., El-Sudany A.M., 2009. Improving productive and reproductive performance of dual-purpose crossbred hens in the tropics by lecithin supplementation. Trop. Anim. Health Prod. 41, 461-475, https://doi.org/10.1007/s11250008-9209-3

Attia Y.A., Kamel K.I., 2012. Semen quality, testosterone, seminal plasma biochemical and antioxidant profiles of rabbit bucks fed diets supplemented with different concentrations of soybean lecithin. Animal 6, 824-833, https://doi.org/10.1017/ S1751731111002229

Blasco A., Ouhayoun J., 1993. Harmonization of criteria and terminology in rabbit meat research. Revised proposal. World Rabbit Sci. 4, 93-99

Cavaliere G., Trinchese G., Bergamo P. et al., 2016. Polyunsaturated fatty acids attenuate diet induced obesity and insulin resistance, modulating mitochondrial respiratory uncoupling in rat skeletal muscle. PLoS ONE 11, e0149033, https://doi. org/10.1371/journal.pone.0149033

Celebi S., Utlu N., 2004. Laying performance, serum lipoproteins, cholesterol and triglyceride of hens as influenced by dietary fat sources. J. Appl. Anim. Res. 25, 121-124, https://doi.org/10.1 080/09712119.2004.9706488

Dewi L., 2016. The effect of lecithin on liver function of white rats (Rattus norvegicus) induced carbon tetrachloride. BioMed. Eng. 2, 5-10

Endo A., 1992. The discovery and development of HMG-CoA reductase inhibitors. J. Lipid Res. 33, 1569-1582

Ferreira D.F., 2011. Sisvar: a computer statistical analysis system. Cienc. Agrotec. 35, 1039-1042, https://doi.org/10.1590/ S1413-70542011000600001

Folch J., Lees M., Sloane Stanley G.H., 1957. A simple method for the isolation and purification of total lipids from animal tissues. J. Biol. Chem. 226, 497-509

Gaafar H.M.A., Abd El-Lateif A.I.A., Abd El-Hady S.B., 2010. Effect of partial replacement of berseem hay by ensiled and dried sugar beet tops on performance of growing rabbits. Researcher 2(9), 10-15 
Gidenne T., Lebas F., Fortun-Lamothe L., 2010. Feeding behaviour in rabbits. In: C. de Blas, J. Wiseman. Nutrition of the Rabbit. CAB International Press. Wallingford (UK), pp. 233-252, https://doi.org/10.1079/9781845936693.0233

Habeeb A.A.M., El-Maghawry A.M., Marai I.F.M., Gad A.E., 1998. Physiological thermoregulation mechanism in rabbits drinking saline water under hot summer conditions. In Proceedings of the $1^{\text {st }}$ Conference on Animal Production and Health in Semi Arid Areas. El-Arish (Egypt), pp. 443-456

Habeeb A.A.M., El-Masry K.A., Aboulnaga A.I., Kamal T.H., 1996. The effect of hot summer climate and level of milk yield on blood biochemistry and circulating thyroid and progesterone hormones in Friesian cows. Arab J. Nucl. Sci. Appl. 29, 161-173

Habeeb A.A.M., Marai A.F.M., El-Maghawry A.M., Gad A.E., 1997. Growing rabbits as affected by salinity in drinking water under winter and hot summer conditions of Egypt. Egypt. J Rabbit Sci. 7, 81-94

Hao Y., Gu X.H., Wang X.L., 2012. Overexpression of heat shock protein 70 and its relationship to intestine under acute heat stress in broilers: 1. Intestinal structure and digestive function. Poult. Sci. 91, 781-789, https://doi.org/10.3382/ps.2011-01627

Huang J., Yang D., Gao S., Wang T., 2008. Effects of soy-lecithin on lipid metabolism and hepatic expression of lipogenic genes in broiler chickens. Livest. Sci. 118, 53-60, https://doi. org/10.1016/j.livsci.2008.01.014

Kalmath G.P., Swamy M.N., Yathiraj S., 2013. Effect of summer stress and supplementation of vitamin $\mathrm{E}$ and selenium on serum lipid profile in Hallikar cattle. Int. J. Sci. Res. 4, 95-97

Khalel M.S., Shwerab A.M., Hassan A.A., Yacout M.H., El-Badawi A.Y., Zaki M.S., 2014. Nutritional evaluation of Moringa oleifera fodder in comparison with Trifolium alexandrinum (berseem) and impact of feeding on lactation performance of cows. Life Sci. J. 11, 1040-1054, https://doi.org/10.7537/marslsj111014.158

Le Blanc M.J., Brunet S., Bouchard G., Lamireau T., Yousef I.M., Gavino V., Lévy E., Tuchweber B., 2003. Effects of dietary soybean lecithin on plasma lipid transport and hepatic cholesterol metabolism in rats. J. Nutr. Biochem. 14, 40-48, https:// doi.org/10.1016/S0955-2863(02)00253-X

Lin Y., Meijer G.W., Vermeer M.A., Trautwein E.A., 2004. Soy protein enhances the cholesterol-lowering effect of plant sterol esters in cholesterol-fed hamsters. J. Nutr. 134, 143-148

Liu D., Ma F., 2011. Soybean phospholipids. In: D. Krezhova (Editor). Recent Trends for Enhancing the Diversity and Quality of Soybean Products. InTech. Rijeka (Croatia), https://doi. org/10.5772/20986

Maertens L., Huyghebaert G., de Groote G., 1986. Digestibility and digestible energy content of various fats for growing rabbits. Cuni-Sci. 3, 7-14

Marai I.F.M., Habeeb A.A.M., Gad A.E., 2005. Tolerance of imported rabbits grown as meat animals to hot climate and saline drinking water in subtropical environment of Egypt. Anim. Sci. 81, 115-123, https://doi.org/10.1079/ASC41710115000

Nishimukai M., Hara H., Aoyama Y., 2003. Enteral administration of soybean lecithin enhanced lymphatic absorption of triacylglycerol in rats. Br. J. Nutr. 90, 565-571, https://doi.org/10.1079/ BJN2003946
Ondruška L., Chrastinová L., Chrenek P., Rafay J., Parkányi V., 2010. Digestibility of nutrients by transgenic and non-transgenic rabbits. Slovak J. Anim. Sci. 43, 210-214

Ondruska L., Rafay J., Okab A.B. et al., 2011. Influence of elevated ambient temperature upon some physiological measurements of New Zealand White rabbits. Vet. Med. 56, 180-186

Qiu Y.-D., Wang S., Yang Y., Yan X.-P., 2012. Omega-3 polyunsaturated fatty acids promote liver regeneration after $90 \%$ hepatectomy in rats. World J. Gastroenterol. 18, 3288-3295, https:// doi.org/10.3748/wjg.v18.i25.3288

Radwan S.S., 1978. Coupling of two-dimensional thin-layer chromatography with gas chromatography for the quantitative analysis of lipid classes and their constituent fatty acids. J. Chromatogr. Sci. 16, 538-542, https://doi.org/10.1093/chromsci/16.11.538

Ramprasath V.R., Jones P.J.H., Buckley D.D., Woollett L.A., Heubi J.E., 2012. Decreased plasma cholesterol concentrations after PUFA-rich diets are not due to reduced cholesterol absorption/synthesis. Lipids 47, 1063-1071, https://doi. org/10.1007/s11745-012-3708-8

Routman K.S., Yoshida L., Frizzas de Lima A.C., Macari M., Pizauro J.M. Jr., 2003. Intestinal and pancreas enzyme activity of broilers exposed to thermal stress. Rev. Bras. Cienc. Avic. 5, 23-27, https://doi.org/10.1590/\$1516-635X2003000100003

Sauvant D., Peres J.-M., Tran G. (Editors), 2004. Tables of Composition and Nutritional Value of Feed Materials - Pigs, Poultry, Cattle, Sheep, Goats, Rabbits, Horses and Fish. Wageningen Academic Publishers. Wageningen (the Netherlands), https:// doi.org/10.3920/978-90-8686-668-7

Scholfield C.R., 1981. Composition of soybean lecithin. J. Am. Oil Chem. Soc. 58, 889-892

Shehata A.S., Sarhan M.A., El-Gendy K.M., 1998. Digestibility, thyroid function and growth performance of New Zealand White rabbits as affected by season of the year and age. Egypt. J. Rabbit Sci. 8, 141-156

Strychalski J., Juśkiewicz J., Gugołek A., Wyczling P., Daszkiewicz T., Zwoliński C., 2014. Usability of rapeseed cake and wheatdried distillers' grains with solubles in the feeding of growing Californian rabbits. Arch. Anim. Nutr. 68, 227-244, https://doi. org/10.1080/1745039X.2014.921482

Zeferino C.P., Moura A.S.A.M.T., Fernandes S., Kanayama J.S., Scapinello C., Sartori J.R., 2011. Genetic group x ambient temperature interaction effects on physiological responses and growth performance of rabbits. Livest. Sci. 140, 177-183, https://doi.org/10.1016/j.livsci.2011.03.027

Zwoliński C., Gugołek A., Strychalski J., Kowalska D., ChwastowskaSiwiecka I., Konstantynowicz M., 2017. The effect of substitution of soybean meal with a mixture of rapeseed meal, white lupin grain, and pea grain on performance indicators, nutrient digestibility, and nitrogen retention in Popielno White rabbits. J. Appl. Anim. Res. 45, 570-576, https://doi.org/10.1080/097 12119.2016.1233107 